\title{
Incidental catch of the rare shortbill spearfish (Tetrapturus angustirostris) by the tuna purse seine fleet in the eastern tropical Pacific Ocean
}

\section{Captura incidental del poco común marlín trompa corta (Tetrapturus angustirostris) por la flota atunera con redes de cerco en el océano Pacífico oriental tropical}

\author{
Emigdio Marín-Enríquez ${ }^{*}$, Arturo Muhlia-Melo \\ Centro de Investigaciones Biológicas del Noroeste, Ave. Instituto Politécnico Nacional, S/N, colonia Playa Palo \\ de Santa Rita Sur, CP 23096, La Paz, Baja California Sur, México.
}

* Corresponding author. E-mail: millomarine@gmail.com

\begin{abstract}
The shortbill spearfish (Tetrapturus angustirostris) is a rare, large pelagic fish that inhabits the tropical and temperate waters of the Pacific and Indian Oceans, and it is seldom incidentally captured by the purse seine and longline tuna fleets. It is listed on the International Union for the Conservation of Nature red list as data deficient, with the population likely decreasing. The main objective of this paper is to contribute basic knowledge of the species catch rate, spatial distribution, temporal trends, and association with different types of fishing sets. A 23-year (1993-2015) database of incidental catches was analyzed; data was gathered by the observers from the Inter-American Tropical Tuna Commission aboard vessels from the international tuna purse seine fleet in the eastern tropical Pacific Ocean. We also analyzed time series of sea surface temperature (SST) from different Niño regions, and 2 climatic indices, the Oceanic Niño Index (ONI) and the Pacific Decadal Oscillation (PDO). The database included information from a total of 422,970 sets; of these, $\sim 1 \%$ resulted in a catch of 687 spearfish. Most incidental catches occurred in waters close to the equator $\left(10^{\circ} \mathrm{S}\right.$ to $\left.10^{\circ} \mathrm{N}\right)$, with no apparent seasonal distribution pattern. Time-series analyses showed a significant positive trend in incidental catch ( 4\% per year). Weak negative correlations of incidental catches with El Niño SST and ONI suggest that spearfish prefer cool waters in zones near the Equator. The PDO seemed to be more important to spearfish than El Niño events, and it is likely playing an important role in the positive trend of incidental catches. Most spearfish catches were associated with sets made on floating objects, mainly south of the equator and west of $100^{\circ} \mathrm{W}$, highlighting the oceanic behavior of this species.
\end{abstract}

Key words: incidental catch, tuna purse seiners, apex predators, Pacific Decadal Oscillation, shortbill spearfish.

RESUMEN. El marlín trompa corta (Tetrapturus angustirostris) es un pez pelágico grande poco común que habita las aguas tropicales y templadas del océano Pacífico y del océano Índico, y rara vez es capturado de manera incidental por las flotas atuneras de cerco y de palangre. Está categorizado en la lista roja de la Unión Internacional para la Conservación de la Naturaleza (UICN) como con datos insuficientes y una disminución probable de su población. El objetivo principal de este trabajo es contribuir al conocimiento básico sobre su tasa de captura, distribución espacial, tendencias temporales y asociación con diferentes tipos de lances pesqueros. Se analizó una base de datos de 23 años (1993-2015), la cual fue recopilada por observadores de la Comisión Interamericana del Atún Tropical a bordo de los buques de la flota internacional de pesca de atún con cerco en el océano Pacífico oriental tropical. También analizamos las series de tiempo de la temperatura superficial del mar (TSM) de diferentes regiones influenciadas por eventos El Niño y 2 índices climáticos, el índice oceánico de El Niño (ION) y el índice de la Oscilación Decadal del Pacífico (ODP). La base de datos incluyó un total de 422,970 lances; de estos, $\sim 1 \%$ resultó en una captura de 687 individuos de marlín trompa corta. La mayor parte de la captura incidental ocurrió en aguas cercanas al ecuador $\left(10^{\circ} \mathrm{S}\right.$ a $\left.10^{\circ} \mathrm{N}\right) \sin$ ningún patrón de distribución estacional aparente. Los análisis de las series de tiempo mostraron que existe una tendencia positiva significativa en la captura incidental ( $4 \%$ por año). Las correlaciones negativas débiles de las capturas incidentales con la TSM de El Niño y con ION sugieren que el marlín trompa corta prefiere las aguas templadas de las zonas cercanas al ecuador. El ODP pareció ser más importante para el marlín trompa corta que los eventos El Niño, y seguramente desempeña un papel importante en la tendencia positiva de la captura incidental. La mayor parte de la captura de marlín trompa corta está relacionada con lances realizados sobre objetos flotantes, principalmente al sur del ecuador y al oeste de $100^{\circ} \mathrm{W}$, lo cual resalta el comportamiento oceánico de esta especie.

Palabras clave: captura incidental, atuneros con redes de cerco, depredadores apicales, Oscilación Decadal del Pacífico, marlín trompa corta.

\section{INTRODUCTION}

Billfish are large oceanic and epipelagic organisms that can be found in all the tropical and temperate seas of the world. The 2 families comprising all billfish species are Istiophoridae (marlins, sailfishes, and spearfishes) and Xiphiidae (a singlespecies family comprising the swordfish, Xiphias gladius).

\section{INTRODUCCIÓN}

Los peces picudos son organismos oceánicos epipelágicos de gran tamaño que se pueden encontrar en todos los mares tropicales y templados del mundo. Las 2 familias que engloban todas las especies de peces picudos son Istiophoridae (marlines, peces vela y agujas) y Xiphiidae 
The distribution of billfish and other tropical pelagic fish is affected by the seasonal and interannual variations of sea surface temperature (SST). For example, Norton (1999) found that the preferred habitat of the dolphinfish (Coryphaena hippurus) expands northwards in the eastern Pacific Ocean during extreme interannual events like the 1997-1998 El Niño. Farrell et al. (2014) found that SST was one of the variables that most influenced dolphinfish catch in the western Atlantic. Su et al. (2008) suggested that blue marlin (Makaira nigricans) prefer waters with SST values between 27 and $30^{\circ} \mathrm{C}$. Martinez-Rincon et al. (2015) reported that sailfish (Istiophorus platypterus) catch was higher when SST values were $>26^{\circ} \mathrm{C}$. Thermal preferences are well known for some billfish species but they have been less explored for spearfish (Boyce et al. 2008).

Although considered one of the largest predators in the tropical food web (Lehodey 2004), the shortbill spearfish (hereafter spearfish; Tetrapturus angustirostris Tanaka, 1915) is one of the smallest members of the Istiophoridae family (on average $\sim 140 \mathrm{~cm}$ in fork-eye length and $\sim 18 \mathrm{~kg}$ in weight; Nakamura 1985). This species inhabits mainly the oceanic tropical and temperate waters of the Pacific and Indian oceans, with rare sightings in the Atlantic Ocean (Nakamura 1985). These fish are incidentally caught by the tuna purse seine and longline fleets and very occasionally by the surface-trolling fleet (Nakamura 1985). Spearfish are believed to spawn during the winter months in offshore waters with SST close to $25^{\circ} \mathrm{C}$ (Nakamura 1985). Their feeding habits are different around the world. In the eastern Pacific Ocean, for example, they feed on a variety of cephalopods and fish (Gempylidae, Scombridae, Exocotidae, Stromatidae; Nakamura 1985), and in the western Indian Ocean this species is thought to prey on fish mainly in the mixed layer (Ménard et al. 2013).

After Nakamura's (1985) seminal work on billfish, only few papers about the spearfish have been published, most focusing on topics unrelated to fisheries, such as food poisoning issues (e.g., Kaneko and Ralston 2007, Chen et al. 2010). According to phylogenetic analysis, Collette et al. (2006) suggested that spearfishes should be classified in their own genera (Tetrapturus), apart from all marlin species. Amandè et al. (2010) found that spearfish accounted for only $0.3 \%$ of the total bycatch made by the tuna purse seine fleet in the Atlantic Ocean from 2003 to 2007. Polovina et al. (2009) suggested that the ecosystem shift to increased relative abundance of mid-trophic, fast-growing predators was likely the result of a decrease in the catch rates of apex predators (including spearfish) in the subtropical North Pacific. Using data from longline surveys in the Northeast Pacific Ocean, Shimose et al. (2010) found that spearfish have specific habitat preferences; all spearfish catches occurred in the open ocean, between $\sim 15^{\circ} \mathrm{N}$ and $20^{\circ} \mathrm{N}$, where the species fed mainly on fish from the Molidae family.

To the best of our knowledge, no quantitative analysis including spearfish incidental catch, spatial distribution, (una familia constituida por una única especie, el pez espada, Xiphias gladius).

La distribución de peces picudos y otros peces pelágicos tropicales es afectada por las variaciones estacionales e interanuales de la temperatura superficial del mar (TSM). Por ejemplo, Norton (1999) encontró que el hábitat preferencial del dorado (Coryphaena hippurus) se expande hacia el norte en el océano Pacífico oriental durante eventos interanuales extremos, como El Niño 1997-1998. Farrell et al. (2014) encontraron que la TSM era una de las variables que más influía en la captura del dorado en el Atlántico occidental. $\mathrm{Su}$ et al. (2008) sugirieron que la aguja azul (Makaira nigricans) prefiere aguas con valores de TSM de 27 a $30{ }^{\circ} \mathrm{C}$. Martinez-Rincon et al. (2015) reportaron que la captura del pez vela (Istiophorus platypterus) era mayor cuando los valores de TSM eran $>26^{\circ} \mathrm{C}$. Las preferencias térmicas de algunas especies de peces picudos son bien conocidas, pero las de los peces aguja se han explorado en menor medida (Boyce et al. 2008).

Aunque es considerado uno de los depredadores más grandes en la cadena trófica tropical (Lehodey 2004), el marlín trompa corta (Tetrapturus angustirostris Tanaka, 1915) es uno de los miembros más pequeños de la familia Istiophoridae (en promedio $\sim 140 \mathrm{~cm}$ de largo de horquilla a ojo y $\sim 18 \mathrm{~kg}$ de peso; Nakamura 1985). Esta especie habita principalmente las aguas oceánicas tropicales y templadas de los océanos Pacífico e Índico, con pocos avistamientos en el océano Atlántico (Nakamura 1985). Estos peces son capturados incidentalmente por la flota atunera que pesca con cerco y la flota palangrera, y muy ocasionalmente en la pesca deportiva con curricanes de superficie (Nakamura 1985). Se piensa que el desove de esta especie ocurre durante los meses de invierno en aguas oceánicas con TSM cercanas a $25^{\circ} \mathrm{C}$ (Nakamura 1985). Los hábitos alimenticios de esta especie varían alrededor del mundo. En el océano Pacífico oriental, por ejemplo, se alimenta de una variedad de cefalópodos y peces (Gempylidae, Scombridae, Exocotidae, Stromatidae; Nakamura 1985), y se piensa que en el océano Índico occidental se alimenta en la capa de mezcla, donde depreda peces, principalmente (Ménard et al. 2013).

Después del trabajo distinguido de Nakamura (1985) sobre peces picudos, se han publicado pocos artículos referentes al marlín trompa corta, la mayoría centrados en temas ajenos a las pesquerías, como problemas de intoxicación alimenticia (e.g., Kaneko y Ralston 2007, Chen et al. 2010). Collette et al. (2006) sugirieron, con base en un análisis filogenético, que los peces aguja deberían de estar clasificados bajo un género propio (Tetrapturus), separados de todas las especies de marlín. Amandè et al. (2010) encontraron que el marlín trompa corta sólo representó el $0.3 \%$ de toda la captura incidental hecha por la flota atunera que operó con redes de cerco en el océano Atlántico de 2003 a 2007. Polovina et al. (2009) sugirieron que el cambio en el ecosistema hacia el incremento en la abundancia relativa de los depredadores de rápido crecimiento y de nivel trófico medio probablemente podría deberse 
temporal trends, relation with SST/climatic indexes, and affinity for certain fishing conditions (set types) in the Pacific Ocean has been published. Additionally, the International Union for the Conservation of Nature (IUCN) has listed this species in the red list of threatened species as "data deficient". Regarding spearfish, the IUCN suggests that "given that it is taken with the same gear as the Blue Marlin and Stripped Marlin, [...] the population of this species is declining as well, but there's no data to quantify this" (Collette et al. 2011). Therefore, the main objective of this paper is to provide basic information on spearfish spatial distribution using a long-term database.

\section{MATERIALS AND METHODS}

\section{Fishery data base}

A 23-year (1993-2015) database of spearfish incidental catch was analyzed for this study. The data from this database was gathered by on-board scientific observers from the Inter-American Tropical Tuna Commission (IATTC). The IATTC requires that one observer be aboard every class- 6 tuna purse seine vessel ( $>435 \mathrm{~m}^{3}$ storage capacity) in every fishing trip (IATTC 2009). The database included total number of spearfish, total number of purse seine sets, type of set (fishing indicator: dolphin, unassociated, and floating object), and geographical coordinates (longitude, latitude), all aggregated in monthly $1^{\circ} \times 1^{\circ}$ quadrants.

\section{Numerical procedures}

Incidental catch was standardized using the total number of sets as fishing effort in the following equation:

$$
\operatorname{ICPUE}_{\mathrm{i}}=\frac{\mathrm{SSP}_{\mathrm{i}}}{\mathrm{NS}_{\mathrm{i}}}
$$

where ICPUE $\mathrm{i}_{\mathrm{i}}$ is the incidental catch per unit effort in number of fish per set, $\mathrm{SSP}_{\mathrm{i}}$ is the total number of caught spearfish, and $\mathrm{NS}_{\mathrm{i}}$ is the total number of purse seine sets, all for ith quadrant.

In order to evaluate the seasonal variation of the spatial distribution of ICPUE, a quarterly approach was used. In this approach, months from January to March were considered the winter season, from April to June spring, from July to September summer, and from October to December autumn. Because the incidental catch vector was notoriously skewed (non-normal appearance), a Kruskal-Wallis test was applied to assess any possible seasonal variation. Quarterly maps were created by aggregating the number of fish per set per quadrant (latitude, longitude) for each of the 4 seasons.

To assess the possible temporal trends in ICPUE, a time series was built by calculating the mean for each month in the 23 years. To enhance visual interpretation of the incidental catch time series, raw data was smoothed using both the smooth and the smooth.spline functions in R's base a una disminución en las tasas de captura de los depredadores apicales (incluido el marlín trompa corta) en el Pacífico Norte subtropical. Shimose et al. (2010) usaron datos de monitoreo de la pesca con palangre en el océano Pacífico nororiental y encontraron que el marlín trompa corta tiene preferencias de hábitat; toda la captura del marlín trompa corta ocurrió en la parte oceánica, entre $\sim 15^{\circ} \mathrm{N}$ y $20^{\circ} \mathrm{N}$, donde la especie se alimentó principalmente de peces de la familia Molidae.

Hasta donde sabemos, no se ha publicado un análisis cuantitativo del marlín trompa corta que incluya su captura incidental, distribución espacial, tendencias en el tiempo, relaciones con la TSM e índices climáticos y afinidades con ciertas condiciones pesqueras (tipos de lances) en el océano Pacífico. Adicionalmente, la Unión Internacional para la Conservación de la Naturaleza (UICN) incluyó a esta especie en su lista roja de especies amenazadas, bajo la categoría de "datos insuficientes". Respecto al marlín trompa corta, esta organización sugiere que, "dado que es capturada con el mismo equipo que la aguja azul y el marlín rayado, [...] la población de esta especie probablemente también está disminuyendo, pero no hay datos para poder cuantificar esto" (Colette et al. 2011). Por lo tanto, el objetivo principal de esta contribución es proporcionar información básica sobre la distribución espacial del marlín trompa corta utilizando una base de datos de largo plazo.

\section{MATERIALES Y MÉTODOS}

\section{Base de datos pesqueros}

Para este estudio, se analizó una base de datos de 23 años (1993-2015) de captura incidental de marlín trompa corta. La información para esta base de datos fue recolectada a bordo de embarcaciones por observadores científicos de la Comisión Interamericana del Atún Tropical (CIAT). La CIAT exige que un observador esté a bordo de cada embarcación atunera de cerco de clase 6 (capacidad de carga $>435 \mathrm{~m}^{3}$ ) en cada viaje (IATTC 2009). La base de datos incluyó el número total de individuos de marlín trompa corta, el número total de lances con redes de cerco, el tipo de lance (indicadores pesqueros: delfín, no asociado y objeto flotante), y las coordenadas geográficas (latitud, longitud), todos agregados en cuadrantes mensuales de $1^{\circ} \times 1^{\circ}$.

\section{Procedimientos numéricos}

La captura incidental se estandarizó utilizando el número total de lances como esfuerzo pesquero en la siguiente ecuación:

$$
\operatorname{CIPUE}_{\mathrm{i}}=\frac{\mathrm{MTC}_{\mathrm{i}}}{\mathrm{TL}_{\mathrm{i}}},
$$

donde, para el cuadrante enésimo i, $\mathrm{CIPUE}_{\mathrm{i}}$ es la captura incidental por unidad de esfuerzo en número de peces por lance, $\mathrm{MTC}_{\mathrm{i}}$ es el número total de individuos de marlín trompa corta 
stats package (R Core Team 2016) and the default arguments. While smooth uses Tukey's running median method, smooth.spline uses a more complex method, a cubic spline smoother. Smooth produced a curve with blunt ridges and smooth.spline produced a rather flat curve, so we decided to use a combination of booth smoothing techniques. The possible trends in the incidental catch time series were explored using a simple linear regression analysis, where the hypothesis that parameter $b$ of the fitted regression model equals zero was tested (positive and different from zero $b$ values indicating a positive trend, and vice versa; Polovina et al. 2009). The linear regression model was applied using R's base stats library (R Core Team 2016). For all statistical tests, we considered a confidence level of $95 \%$. Annual percent change rate in spearfish ICPUE was calculated by dividing the slope by the intercept of the fitted linear model and by multiplying the result by 12 to convert from monthly rate to yearly rate and then by 100 to convert to percentage (Polovina et al. 2009). To evaluate the possible effect of SST variations on spearfish catch, we explored the relation between the incidental catch time series and the SST monthly mean values extracted from the Niño 1+2, 3, and 3.4 regions, the Oceanic Niño Index (ONI), and the Pacific Decadal Oscillation (PDO) index by performing a cross-correlation analysis using the $c c f$ function of the $\mathrm{R}$ stats package (R Core Team 2016). We decided not to include SST values extracted from the Niño 4 region, because the portion of this area that is not included in the 3.4 region falls outside our study area. The same approach that was applied to the incidental catch data was applied here to detect possible trends in the environmental time-series data. Information on the SST in the Niño regions and ONI can be obtained from the National Centers for Environmental Information website (https://www.ncdc. noaa.gov/teleconnections/enso/indicators/sst.php) of the National Oceanic and Atmospheric Administration (USA). A brief description of the PDO and corresponding data can be obtained from the same website at https://www.ncdc. noaa.gov/teleconnections/pdo/.

\section{Type of set}

In order to explore the spatial affinity between spearfish and each type of set, histograms of the number of fish caught per set were created for both latitude and longitude for each type of set by using an arbitrary bin of $5^{\circ}$ in both cases.

\section{RESULTS}

\section{General picture}

Over the 23 years, a total of 422,970 purse seine sets were carried out in the study area and 4,333 sets were carried out in cells where at least one spearfish was caught. A total of 687 individuals were caught, and 292.95 fish were caught per set $($ mean $=0.002$ fish per set; $\mathrm{SD}=0.05)$. Maximum capturados y $\mathrm{TL}_{\mathrm{i}}$ es el número total de lances con redes de cerco.

Para evaluar la variación estacional de la distribución espacial de la CIPUE, se utilizó un enfoque trimestral. Según este enfoque, los meses de enero a marzo se consideraron como la temporada de invierno, de abril a junio primavera, de julio a septiembre verano y de octubre a diciembre otoño. Debido a que el vector de la captura incidental estaba notoriamente sesgado (distribución no normal), se aplicó la prueba de Kruskal-Wallis para evaluar la posible variación estacional. Se crearon mapas trimestrales agregando el número de peces por lance para cada cuadrante (latitud, longitud), para cada una de las 4 estaciones.

Para evaluar las posibles tendencias temporales en la CIPUE, se construyó una serie de tiempo calculando el promedio para cada mes de los 23 años. Para mejorar la interpretación visual de la serie de tiempo de la captura incidental, los datos brutos se suavizaron utilizando las funciones smooth y smooth.spline del paquete stats base de $\mathrm{R}$ (R Core Team 2016) y los argumentos predeterminados. La función smooth utiliza el método de medianas móviles de Tukey, mientras que la función smooth.spline utiliza un método más complejo, el suavizador de spline cúbico. La función smooth produjo una curva con crestas suaves y smooth.spline produjo una curva bastante plana; por lo tanto, decidimos usar una combinación de ambas técnicas de suavización. Para evaluar las posibles tendencias en la serie de tiempo de la captura incidental, utilizamos un análisis de regresión lineal simple, donde probamos la hipótesis de que el parámetro $b$ del modelo de regresión ajustado es igual a cero (valores de $b$ positivos y diferentes de cero indican una tendencia positiva y viceversa; Polovina et al. 2009). El modelo de regresión lineal se aplicó usando la librería de stats base de R (R Core Team 2016). Consideramos un nivel de confianza del $95 \%$ en todas las pruebas estadísticas. Para calcular el porcentaje de la tasa de cambio anual de la CIPUE del marlín trompa corta, se dividió la pendiente entre el intercepto del modelo lineal ajustado y se multiplicó el resultado por 12 para convertirlo de una tasa mensual a una tasa anual y posteriormente por 100 para convertirlo en un porcentaje (Polovina et al. 2009). Para evaluar el posible efecto de las variaciones de la TSM en la captura del marlín trompa corta, exploramos la relación entre la serie de tiempo de la captura incidental y los valores mensuales promedio de la TSM extraídos de las regiones Niño 1+2, 3 y 3.4, el Índice Oceánico de El Niño (ION) y el índice de la Oscilación Decadal del Pacífico (ODP) mediante un análisis de correlación cruzada con la función $c c f$ del paquete stats de R (R Core Team 2016). Decidimos no incluir los valores de la TSM extraídos de la región Niño 4 debido a que la porción de esta área que no está incluida en la región 3.4 cae fuera de nuestra área de estudio. Se aplicó el mismo procedimiento que se aplicó a los datos de la captura incidental, para detectar las posibles tendencias de los datos de las series de tiempo de los factores ambientales. La información 
values of 4 fish per set were found for February 1995, June 2002, July 2013, and October 2015. There were small seasonal differences in the amount of fish caught during summer, spring, autumn, and winter, with $29 \%, 28 \%, 24 \%$, and $19 \%$ of total fish per set $(85.26,81.76,71.36$, and 54.56 fish per set), respectively; these differences were not significant $\left(K_{(3,136335)}=\right.$ 7.42; $P=0.06$ ).

Spatially, most of the incidental catch occurred in a zone near the equator, from $10^{\circ} \mathrm{S}$ to $10^{\circ} \mathrm{N}$, with some quadrants displaying "high" catch in the Southern Hemisphere during the summer months. One maximum (4 fish per set) occurred in each of the 4 seasons: one in the Central American coast during winter, one in the open ocean $\left(3^{\circ} \mathrm{N}, 130^{\circ} \mathrm{W}\right)$ during spring, one at the same latitude but closer to the coast (approximately $102^{\circ} \mathrm{W}$ ) during summer, and one near the South American coast during autumn (Fig. 1).

\section{Temporal trend}

The smoothed time series showed 4 peaks of incidental catch during 1996, 2007, 2013, and 2015, with one peak per year (Fig. 2). The linear regression model fit showed a positive trend in the incidental catch time series $\left(a=1.39 \times 10^{-3}\right.$, $\left.P<0.05 ; b=4.78 \times 10^{-6}, P<0.05\right)$. The incidental catch of spearfish increased at a rate of $\sim 4.15 \%$ per year. Crosscorrelation analyses showed an inverse relation between spearfish catch and environmental data; however, only the correlation with SST from the Niño 3 and 3.4 regions and the PDO index, found with lags of 11, 9, and 2 months, was significant (Table 1). The PDO was the environmental variable that showed the highest absolute correlation value with ICPUE (Table 1), and the only variable to show a significant (negative) temporal trend (Fig. 3, Table 2).

\section{Incidental catch per type of set}

Of the total 292.95 fish per set caught during our study period, $70.98 \%$ (207.95 fish per set) were caught when the fleet fished on floating objects, $19.17 \%$ (56.18 fish per set) were caught on dolphin sets, and 9.8\% (28.81 fish per set) were caught when the fleet targeted free-swimming tuna schools.

The most important mode for incidental catches in sets made on floating objects was found south of the equator, between $5^{\circ} \mathrm{S}$ and $10^{\circ} \mathrm{S}$. On the other hand, the most notorious mode for dolphin sets was found north of the equator, between $5^{\circ} \mathrm{N}$ and $10^{\circ} \mathrm{N}$. No notorious latitudinal mode was found for incidental catches in sets made on free-swimming tuna schools (Fig. 4a).

Incidental catches of spearfish in sets made on floating objects was higher west of $100^{\circ} \mathrm{W}$; the most important mode for dolphin sets was found between $85^{\circ} \mathrm{W}$ and $90^{\circ} \mathrm{W}$ longitude, although there was a similar mode between $120^{\circ} \mathrm{W}$ and $125^{\circ} \mathrm{W}$ longitude. Most incidental catches in sets on free-swimming tuna schools occurred to east of $100^{\circ} \mathrm{W}$ (Fig. 4b). sobre las TSM de las regiones Niño y los datos del ION se pueden obtener del sitio web del Centro Nacional para la Información Ambiental de la Administración Nacional Oceánica y Atmosférica (EUA) (https://www.ncdc.noaa. gov/teleconnections/enso/indicators/sst.php). Una breve descripción del ODP y los datos correspondientes se pueden obtener de la misma página web en https://www.ndc.noa. gov/teleconnections/pdo/.

\section{Tipo de lance}

Para explorar la afinidad espacial entre el marlín trompa corta y cada tipo de lance, se crearon histogramas del número de peces capturados por lance, tanto para la latitud como para la longitud, para cada tipo de lance utilizando intervalos arbitrarios de $5^{\circ}$ en ambos casos.

\section{RESUltados}

\section{Cuadro general}

Durante los 23 años, se llevaron a cabo un total de 422,970 lances con redes de cerco en el área de estudio y 4,333 lances en las celdas en las que por lo menos un marlín trompa corta había sido capturado. Se capturaron 687 individuos en total y 292.95 peces por lance (promedio $=0.002$ peces por lance; desviación estándar $=0.05$ ). Se encontraron valores máximos de 4 peces por lance en febrero de 1995, junio de 2002, julio de 2013 y octubre de 2015. Se encontraron pequeñas variaciones estacionales en la cantidad de peces capturados durante el verano, la primavera, el otoño y el invierno, con $29 \%, 28 \%, 24 \%$ y $19 \%$ del total de peces por lance $(85.26,81.76,71.36$ y 54.56 peces por lance), respectivamente; estas diferencias no fueron significativas $\left(K_{(3,136335)}=7.42, P=0.06\right)$.

Espacialmente la mayoría de la captura incidental ocurrió en una zona cercana al ecuador, de $10^{\circ} \mathrm{S}$ a $10^{\circ} \mathrm{N}$, y algunos cuadrantes mostraron "alta" captura en el hemisferio sur durante los meses de verano. Un máximo (4 peces por lance) ocurrió en cada una de las estaciones: uno en la costa centroamericana durante el invierno; uno en mar abierto $\left(\sim 3^{\circ} \mathrm{N}\right.$, $130^{\circ} \mathrm{W}$ ) durante la primavera; uno en la misma latitud, pero más próximo a la costa (aproximadamente a $102^{\circ} \mathrm{W}$ ) durante el verano y uno próximo a la costa sudamericana durante el otoño (Fig.1).

\section{Tendencia temporal}

La serie temporal suavizada mostró 4 picos en la captura incidental del marlín trompa corta durante 1996, 2007, 2013 y 2015, con un pico por año (Fig. 2). El ajuste del modelo de regresión lineal mostró que existe una tendencia positiva en la serie de tiempo de la captura incidental del marlín trompa corta $\left(a=1.39 \times 10^{-3}, P<0.05 ; b=4.78 \times 10^{-6}, P<0.05\right)$. La captura incidental del marlín trompa corta incrementó 


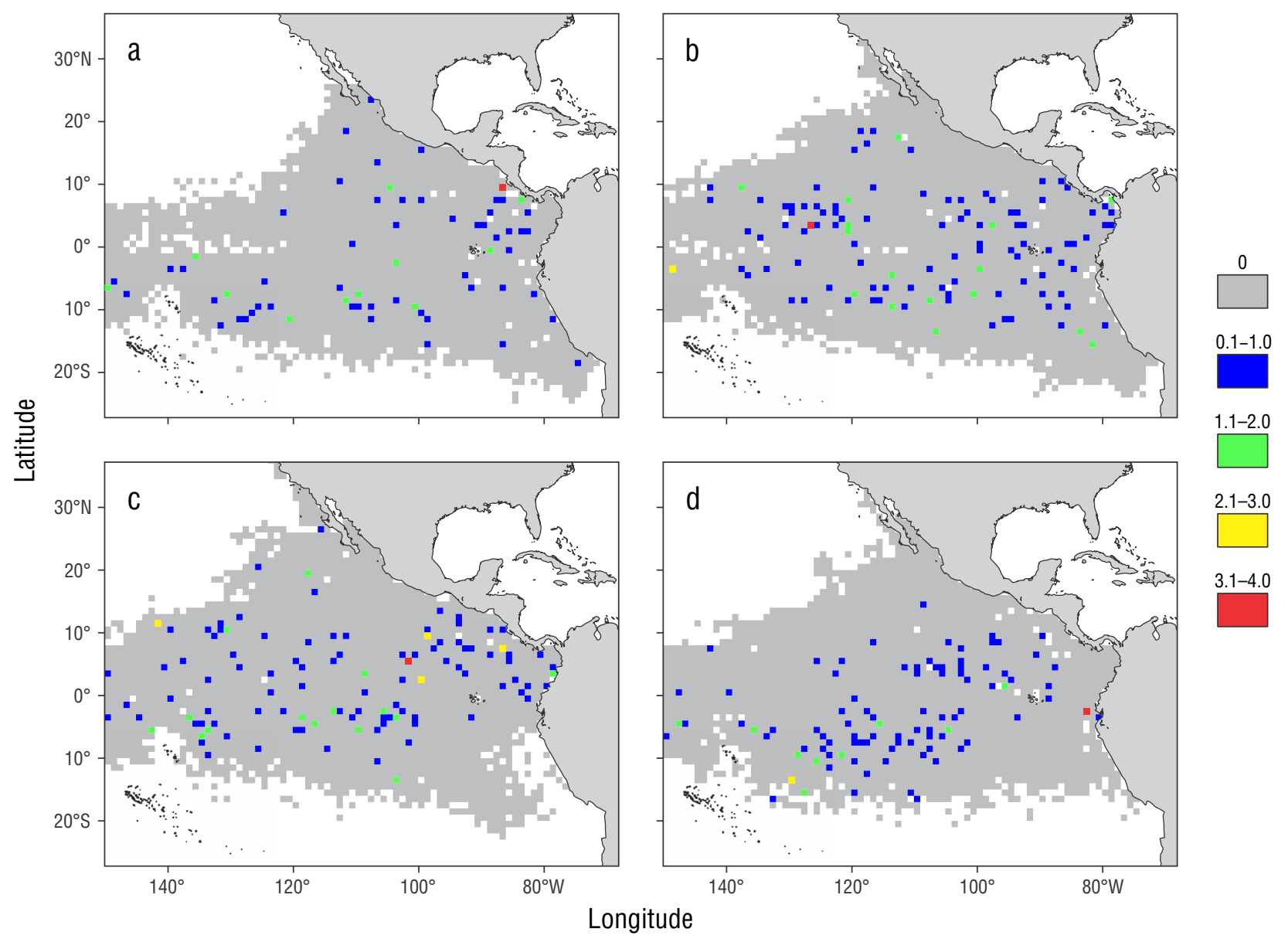

Figure 1. Seasonal spatial distribution of the incidental catch of spearfish in the first quarter (January-March) (a), second quarter (AprilJune) (b), third quarter (July-September) (c), and fourth quarter (October-December) (d). Units in the color scale are number of fish per set.

Figura 1. Distribución espacial estacional de la captura incidental del marlín trompa corta en el primer trimestre (enero-marzo) (a), el segundo trimestre (abril-junio) (b), el tercer trimestre (julio-septiembre) (c) y el cuarto trimestre (octubre-diciembre) (d). Las unidades en la escala de color son número de peces por lance.

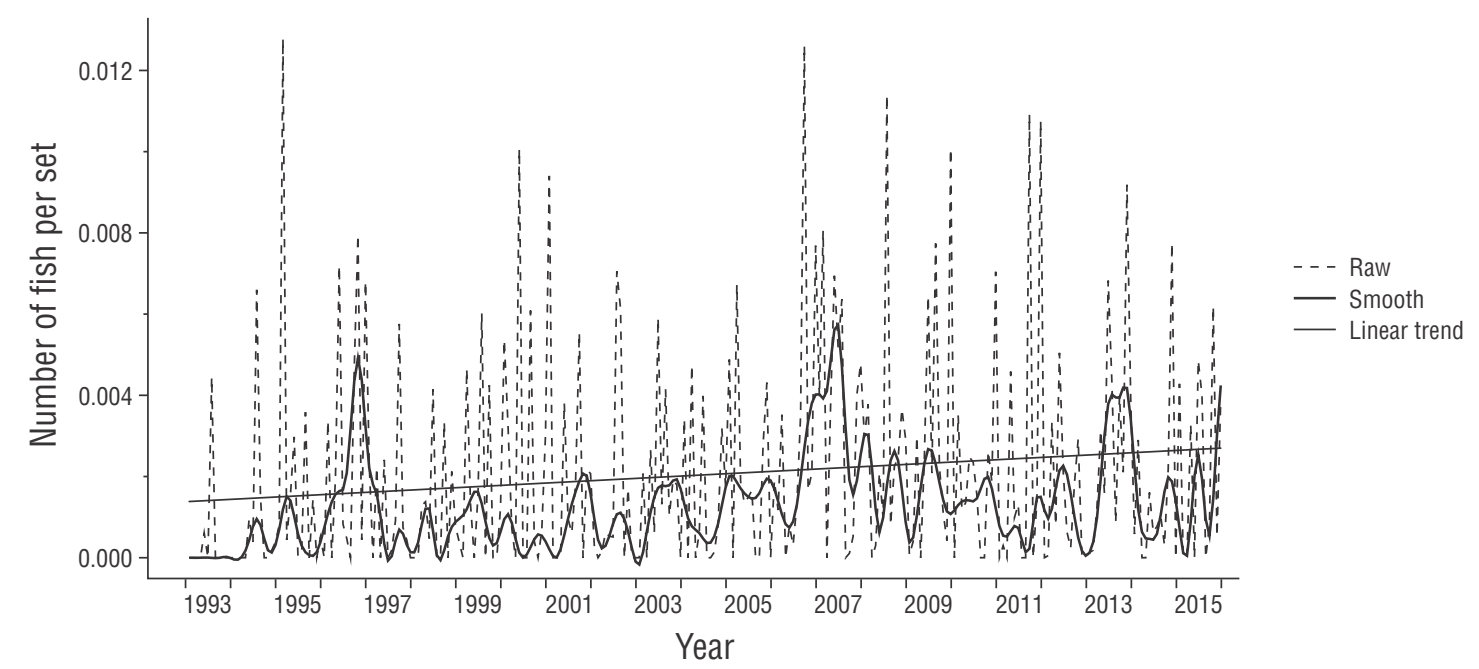

Figure 2. Raw and smoothed time series of the incidental catch of spearfish.

Figura 2. Serie temporal sin procesar y suavizada de la captura incidental del marlín trompa corta. 


\section{Discussion}

Only $\sim 1 \%$ of total purse seine sets resulted in the total incidental catch of spearfish, mostly in the open ocean, highlighting the rareness and oceanic behavior of this species. Shimose et al. (2010) suggested that spearfish occur mainly in areas far from the equator. However, our evidence shows that most spearfish were caught in an area near the equator, from $10^{\circ} \mathrm{S}$ to $10^{\circ} \mathrm{N}$. As Shimose et al. (2010) noted, their results may be true for a specific time of the year (late summer, early fall). In our paper we present a bigger spatiotemporal picture, which helps better understand the spatial distribution of spearfish. In addition to the possible effects of seasonal migration, the fact that the data reported by Shimose et al. (2010) were collected during longline operations could indicate a source of bias in the spearfish catch estimate because longlines can reach up to $250 \mathrm{~m}$ depth (Bigelow et al. 2006), and spearfish are believed to inhabit shallower waters than other billfish (Nakamura 1985); this bias is expected to be lower when using data from purse seine sets, which use surface fishing gear.

The equatorial zone is a highly productive area because of the upwelling events that are generated by the trade winds (Martínez-Rincón et al. 2009); this upwelling process is manifested by a cold water tongue that extends from an area near the Central American coast to the International Date Line (Wyrtki 1981, p. 1206). In the Northern Hemisphere, there is a zone where temperature changes very little and the strong thermoclines occurring outside this cold water tongue, at around $5^{\circ} \mathrm{N}-10^{\circ} \mathrm{N}$, favor the aggregation of some marine mammals and fish (Fiedler et al. 1992, MartínezRincón et al. 2009). The area around the cold water tongue $\left(5^{\circ} \mathrm{N}-10^{\circ} \mathrm{N}\right)$ is an important feeding zone for large pelagic fish such as sharks, tunas, and billfish that feed on crustaceans, fish, and small squid, as a result of the upwelling events that occur in the convergence zone between the South and North Equatorial Currents (Mann and Lazier 1996, Galván-Magaña 1999, Bocanegra-Castillo 2007).

Table 1. Summary of the cross-correlation between the incidental catch of spearfish per unit effort and environmental data. ONI, Oceanic Niño Index; PDO, Pacific Decadal Oscillation.

Tabla 1. Resumen de la correlación cruzada entre la captura incidental del marlín trompa corta por unidad de esfuerzo y los datos ambientales. ONI, Índice Oceánico de El Niño; PDO, Oscilación Decadal del Pacífico.

\begin{tabular}{lccc}
\hline & Correlation $(\rho)$ & Lag (months) & $P(\rho=0)$ \\
\hline Niño 1+2 & -0.113 & 0 & 0.059 \\
Niño 3 & -0.125 & 11 & $<0.050$ \\
Niño 3.4 & -0.135 & 9 & $<0.050$ \\
ONI & -0.109 & 9 & 0.065 \\
PDO & -0.156 & 2 & $<0.050$ \\
\hline
\end{tabular}

a una tasa de $\sim 4.15 \%$ por año. Los análisis de correlación cruzada mostraron una relación inversa entre la captura del marlín trompa corta y los datos ambientales; sin embargo, sólo las correlaciones con las TSM de las regiones Niño 3 y 3.4, y del ODP, que se encontraron con desfases de 11,9 y 2 meses, fueron significativas (Tabla 1). El ODP fue la variable ambiental que mostró el mayor valor absoluto de correlación con la CIPUE (Tabla 1), y la única variable que presentó una tendencia temporal (negativa) significativa (Fig. 3, Tabla 2).

\section{Captura incidental por tipo de lance}

Del total de 292.95 peces por lance capturados durante nuestro periodo de estudio, el 70.98\% (207.95 peces por lance) fue capturado cuando la embarcación pescó sobre objetos flotantes, el $19.17 \%$ (56.18 peces por lance) fue capturado sobre delfín y el 9\% (28.81 peces por lance) fue capturado cuando la embarcación se dirigió a bancos de atún que se desplazaban libremente.

La moda más importante para la captura incidental por lances realizados sobre objetos flotantes se encontró al sur del ecuador, entre $5^{\circ} \mathrm{S}$ y $10^{\circ} \mathrm{S}$. Por otra parte, la moda más notoria para los lances sobre delfín se encontró al norte del ecuador, entre $5^{\circ} \mathrm{N}$ y $10^{\circ} \mathrm{N}$. No se encontró ninguna moda latitudinal notable para la captura incidental relacionada con lances realizados sobre bancos de atún que se desplazaban libremente (Fig. 4a).

La captura incidental del marlín trompa corta por lances realizados sobre objetos flotantes fue más alta al oeste de $100^{\circ} \mathrm{W}$; la moda más importante para los lances sobre delfín se encontró entre las longitudes $85^{\circ} \mathrm{W}$ y $90^{\circ} \mathrm{W}$, aunque hubo una moda similar entre las longitudes $120^{\circ} \mathrm{W}$ y $125^{\circ} \mathrm{W}$. La mayor parte de la captura incidental relacionada con lances realizados sobre bancos de atún que se desplazaban libremente ocurrió al este de $100^{\circ} \mathrm{W}$ (Fig. 4b).

\section{Discusión}

Sólo el $\sim 1 \%$ del total de lances cerqueros resultó en capturas incidentales de marlín trompa corta, la mayoría en mar abierto, lo que destaca la rareza de esta especie y su comportamiento oceánico. Shimose et al. (2010) sugirieron que el marlín trompa corta se presenta principalmente en zonas lejanas al ecuador. Sin embargo, nuestra evidencia muestra que la mayoría de las capturas del marlín trompa corta ocurrió en una zona cerca del ecuador, de $10^{\circ} \mathrm{S}$ a $10^{\circ} \mathrm{N}$. Así como lo destacan Shimose et al. (2010), puede ser que sus resultados sean válidos para una temporada específica del año (finales de verano, principios de otoño). Sin embargo, en este trabajo mostramos un panorama espacial y temporal más amplio, el cual ayuda a entender mejor la distribución espacial del marlín trompa corta. Aunado a los posibles efectos migratorios estacionales, el hecho de que los datos reportados por Shimose et al. (2010) provinieran de operaciones con palangre podría inducir una fuente de 
According to Shimose et al. (2010), spearfish feed mainly on fish from the Molidae family, and "[tend] to avoid the equatorial zone, where preferable prey may not be available." Measurement and count data for members of the Molidae family is scarce (Matsuura 2015). Some Molidae, such as Mola mola, occur seasonally in Pacific Ocean waters off Southern California (USA), suggesting migratory activity (Cartamil and Lowe 2004), presumably in response to a preferred temperature range (Lee 1986). In spite of the possible migratory activity of spearfish prey, spearfish might opportunistically feed on available prey, since Nakamura (1985) noted that spearfish stomach contents vary spatially and seasonally. Seasonal sampling of stomach contents for this species may provide better insights on the factors that determine the spatial distribution of prey.

Polovina et al. (2009) found a decrease in the spearfish catch reported by the Hawaiian longline fishery from 1996 to 2006. Population decrease is assumed by the IUCN (Collette et al. 2011). Our data suggest that, at least in the eastern Pacific Ocean, the spearfish population is on the rise at a rate of $\sim 4 \%$ per year, as evidenced by the positive slope in the linear regression analysis.

The incidental catch of spearfish was significantly correlated with SST extracted from the Niño 3 and 3.4 regions and PDO. However, the significance of correlation tests applied to data sets with a high number of observations should be addressed with care because the value of the coefficient at which the correlation becomes statistically significant is inversely related to the number of observations, so statistically significant correlations may still depict a weak correlation between the 2 variables. In contrast with the higher and sesgo en la estimación de la captura del marlín trompa corta debido a que los palangres pueden alcanzar profundidades de hasta $250 \mathrm{~m}$ (Bigelow et al. 2006), y esta especie aparentemente habita aguas más someras que otros peces picudos (Nakamura 1985); se espera que este sesgo sea menor cuando se utilicen datos de lances con redes de cerco, un equipo de pesca principalmente superficial.

La zona ecuatorial es sumamente productiva debido a los eventos de surgencia generados por los vientos alisos (Martínez-Rincón et al. 2009); este proceso de surgencia se manifiesta como una lengüeta de agua fría que se extiende desde cerca de la costa centroamericana hasta la línea de cambio de fecha internacional (Wyrtki 1981, p. 1206). En el hemisferio norte, hay una zona donde ocurren pocos cambios en la TSM y las termoclinas fuertes que ocurren fuera de esta lengüeta de agua fría, a alrededor de $5^{\circ} \mathrm{N}-10^{\circ} \mathrm{N}$, favorecen la agregación de algunos mamíferos marinos y peces (Fiedler et al. 1992, Martínez-Rincón et al. 2009). La zona alrededor de la lengüeta de agua fría $\left(5^{\circ} \mathrm{N}-10^{\circ} \mathrm{N}\right)$ es una zona de alimentación importante para peces pelágicos grandes como tiburones, atunes y peces picudos que se alimentan de crustáceos, peces y pequeños calamares, producto de los eventos de surgencia que ocurren en la zona de convergencia entre las corrientes ecuatoriales Norte y Sur (Mann y Lazier 1996, Galván-Magaña 1999, Bocanegra-Castillo 2007).

De acuerdo con Shimose et al. (2010) el marlín trompa corta se alimenta principalmente de peces de la familia Molidae y "tiende a evadir la zona ecuatorial, donde puede que su presa de preferencia no esté disponible". Los datos de medidas y conteos de miembros de la familia Molidae son escasos (Matsuura 2015). Algunas especies de Molidae, como

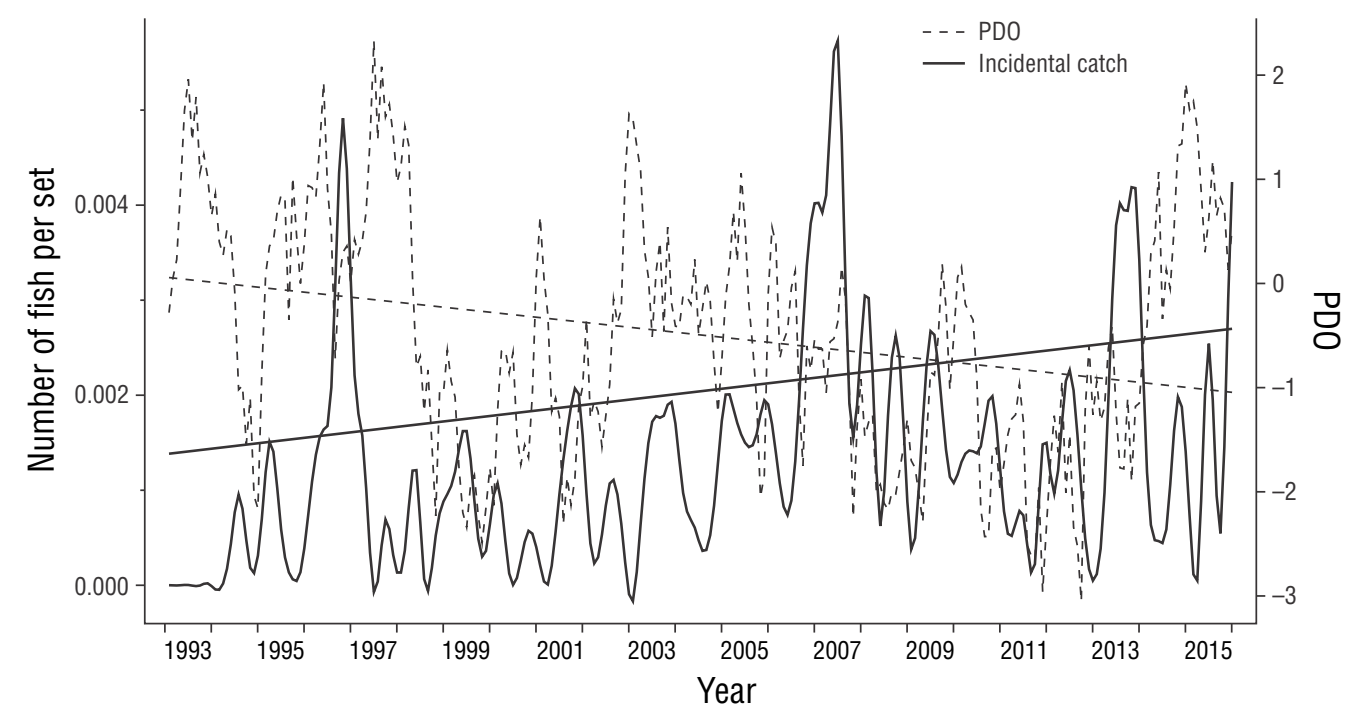

Figure 3. Smoothed time series of the incidental catch of spearfish and Pacific Decadal Oscillation (PDO) time series, with corresponding trend lines.

Figura 3. Serie temporal suavizada de la captura incidental del marlín trompa corta y del índice de la Oscilación Decadal del Pacífico (PDO) con las líneas de tendencia correspondientes. 
more significant correlations found with SST extracted from the Niño 3 and 3.4 regions, correlation between ICPUE and SST from the Niño 1+2 region (the closest one to the coastline) was lower and nonsignificant, which weakly suggests that spearfish are affected mostly by SST variations that are due to processes that occur in the open ocean.

We found negative correlations between ICPUE and SST from the Niño regions, which suggests that spearfish prefer cool waters. However, higher correlations between these variables were found with 9-11 month lags; that is, higher incidental catches occurred $\sim 10$ months after the SST minimum occurred in the Niño regions. The SST minimum in the Niño 3.4 region occurred within the first 2 months of the year, so incidental catch is expected to be higher during winter, when SST starts to decrease towards the end of the year. A plausible explanation is that spearfish arrive in equatorial waters to spawn, since this species is believed to spawn in waters with relatively low temperatures $\left(\sim 25^{\circ} \mathrm{C}\right.$, Nakamura 1985$)$. Another plausible explanation is that spearfish feed on prey that are more abundant during that time of the year. However, we can only speculate on the mechanisms that are responsible for the time lag found between ICPUE and SST because literature concerning the basic biology of spearfish and/or its main prey is notably scarce, and these hypotheses would need to be further investigated.

The PDO is a temporal pattern that affects Pacific Ocean climate in time scales of decades, and it can be viewed as a "long-lived" El Niño climate phenomenon (Mantua and Hare 2002), since the cold and warm phases of both El Niño and the PDO show similar behavior (Mantua et al. 1997). The correlation between ICPUE and PDO was the highest and most direct (2 month lag) of all environmental correlations; moreover, ICPUE and PDO were the only 2 variables that showed a significant trend over time.

With this evidence, we suggest that spearfish inhabit zones close to the equator (e.g., outside the defined Niño zones), where upwelled water is cooler than equatorial waters. Also, spearfish appear to be more affected by environmental

Table 2. Summary of the linear regression mode fitted to environmental data. ONI, Oceanic Niño Index; PDO, Pacific Decadal Oscillation.

Tabla 2. Resumen del modelo de regresión lineal ajustado a los datos ambientales. ONI, Índice Oceánico de El Niño; PDO, Oscilación Decadal del Pacífico.

\begin{tabular}{lccc}
\hline & $a$ & $b$ & $P(b=0)$ \\
\hline Niño 1+2 & 23.220 & -0.0004 & 0.824 \\
Niño 3 & 25.850 & 0.0004 & 0.682 \\
Niño 3.4 & 26.990 & 0.0003 & 0.636 \\
ONI & -0.011 & -0.0001 & 0.853 \\
PDO & 0.060 & -0.0040 & $<0.050$ \\
\hline
\end{tabular}

Mola mola, se presentan estacionalmente en aguas del océano Pacífico frente al sur de California (EUA), lo cual sugiere una actividad migratoria (Cartamil y Lowe 2004), presuntamente como respuesta a un intervalo de temperatura preferido (Lee 1986). Dada la aparente actividad migratoria de las presas del marlín trompa corta, esta especie de picudo posiblemente se alimenta de manera oportunista de las presas que se encuentren disponibles, ya que Nakamura (1985) notó que el contenido de los estómagos del marlín trompa corta varía espacialmente y estacionalmente. Los muestreos estacionales del contenido de los estómagos de esta especie podrían mejorar el entendimiento de los factores que determinan la distribución espacial de sus presas.

Polovina et al. (2009) encontraron una disminución en la captura del marlín trompa corta reportada por la pesquería de palangre hawaiana de 1996 a 2006. La UICN presume una tendencia poblacional descendente (Collette et al. 2011). Nuestros datos sugieren que, al menos en el océano Pacífico oriental, la población del marlín trompa corta está incrementando con una tasa del $\sim 4 \%$ por año, tendencia que fue evidenciada por una pendiente positiva en el análisis de regresión lineal.

La captura incidental del marlín trompa corta se correlacionó significativamente con las TSM extraídas de las regiones Niño 3 y 3.4 , y con la ODP. Sin embargo, se debe tomar con precaución la significatividad de las pruebas estadísticas de correlación aplicadas a conjuntos de datos con un gran número de observaciones, ya que el valor del coeficiente en el cual la correlación se vuelve estadísticamente significativa está inversamente relacionado con el número de observaciones; por tanto, las correlaciones estadísticamente significativas pueden aún representar correlaciones débiles entre 2 variables. En contraste con las correlaciones más altas y significativas encontradas con las TSM extraídas de las regiones Niño 3 y 3.4, la correlación entre la CIPUE y las TSM de las regiones Niño 1+2 (la más cercanas a la línea de costa) fue menor y no fue significativa, lo cual sugiere que, aunque de manera débil, el marlín trompa corta es afectado por las variaciones de TSM que se deben a procesos que ocurren en mar abierto.

Encontramos correlaciones negativas entre la CIPUE y las TSM de todas las regiones Niño, lo cual sugiere que el marlín trompa corta prefiere aguas templadas. No obstante, las correlaciones más altas entre estas variables se encontraron con desfases de 9-11 meses; en otras palabras, encontramos que la mayor parte de la captura incidental ocurrió $\sim 10$ meses después de presentarse la TSM mínima en las regiones Niño. La TSM mínima en la región Niño 3.4 ocurrió dentro de los primeros 2 meses del año, así que se espera la captura incidental sea mayor durante el invierno, cuando la TSM empieza a disminuir hacia finales del año. Una posible explicación es que el marlín trompa corta llega a aguas ecuatoriales para desovar, debido a que se piensa que esta especie desova en aguas con temperaturas relativamente bajas $\left(\sim 25^{\circ} \mathrm{C}\right.$, Nakamura 1985). Otra posible explicación es que el marlín trompa corta se alimenta de presas que son más abundantes 
processes that occur at larger temporal scales than El Niño, such as the PDO. Since we used a standardized relative abundance index (ICPUE) that is not affected by possible temporal changes in fishing effort, we also suggest that the negative trend in PDO was an important factor causing the positive trend in the incidental catch of spearfish because, given the time scales at which the PDO affects climate in the Pacific Ocean, these cooler, preferred waters are expected to remain a longer time in the zone near the equator.

Most spearfish catches were associated with sets on floating objects. The affinity that certain fish species have for floating objects is not fully understood. It is believed that some fish use floating objects to trace high-productivity water masses, since the origin of these objects is usually a high-productivity zone, such as a river mouth (Hall 1992). Some authors suggest that floating objects tend to aggregate around certain oceanographic structures, such as fronts and gyres, where billfish prey also congregate (Sakagawa 1989, cited in Sosa-Nishizaki 1998). Solana-Sansores (2001) showed that the equatorial current system can retain floating objects from different origins in a latitudinal band from $15^{\circ} \mathrm{S}$ to $10^{\circ} \mathrm{N}$ and noted that that purse seine sets on floating objects are becoming more common. This could explain the high incidental catch of spearfish on this type of set, which occurs

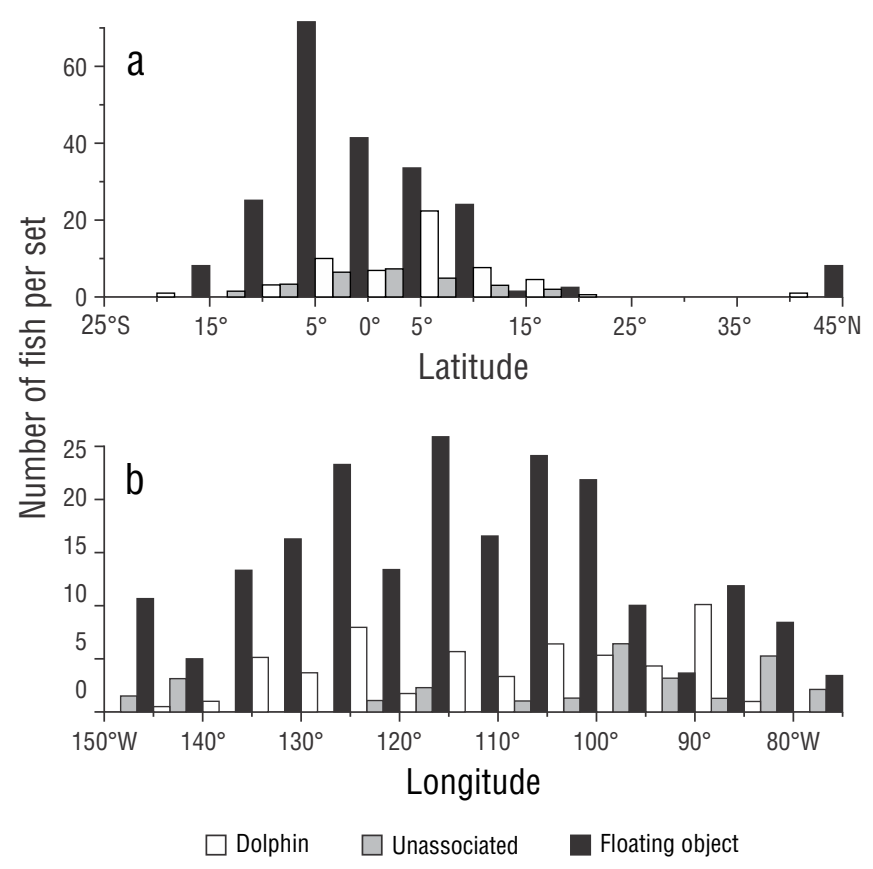

Figure 4. Spatial distribution of total incidental catch of spearfish per unit effort, per type of set (on dolphin, unassociated, and on floating objects) for latitude (a) and longitude (b) during the study period.

Figura 4. Distribución espacial del total de la captura incidental por unidad de esfuerzo del marlín trompa corta por tipo de lance (sobre delfín, no asociado y sobre objetos flotantes), por latitud (a) y longitud (b) durante el periodo de estudio. durante esa temporada del año. Sin embargo, sólo podemos especular acerca de los mecanismos que ocasionaron el desfase encontrado entre la CIPUE y la TSM porque la literatura sobre la biología básica del marlín trompa corta y/o sus presas principales es notablemente escasa, y estas hipótesis necesitarían ser investigadas más a fondo.

La ODP es un patrón temporal que afecta el clima del océano Pacífico en escalas de tiempo de décadas, y puede verse como un fenómeno climático El Niño "longevo" (Mantua y Hare 2002), ya que las fases frías y cálidas tanto de El Niño como de la ODP muestran comportamientos similares (Mantua et al. 1997). La correlación entre la captura del marlín trompa corta y la ODP fue la más alta y más directa ( 2 meses de desfase) de todas las correlaciones ambientales; además, la captura del marlín trompa corta y la ODP fueron las únicas 2 variables que mostraron una tendencia significativa a lo largo del tiempo.

Tomando en cuenta esta evidencia, sugerimos que el marlín trompa corta habita zonas cercanas al ecuador (e.g., fuera de las zonas El Niño definidas), donde las aguas de surgencia son de menor temperatura que las aguas del ecuador. Además, el marlín trompa corta parece estar más afectado por procesos ambientales que ocurren a escalas temporales más amplias que eventos de El Niño, como la ODP. Ya que utilizamos un índice de abundancia relativa estandarizado (CIPUE) que no es afectado por posibles cambios temporales en el esfuerzo pesquero, también sugerimos que la tendencia negativa en la ODP es una causa importante de la tendencia positiva de la captura incidental del marlín trompa corta porque, dadas las escalas temporales en las que la ODP afecta el clima en el océano Pacífico, se espera que estas aguas más frías y preferidas permanezcan más tiempo en la zona cercana al ecuador.

La mayoría de la captura incidental del marlín trompa corta se asoció a los lances realizados sobre objetos flotantes. Las causas de la afinidad de ciertas especies de peces por objetos flotantes no son completamente comprendidas. Se piensa que algunos peces usan los objetos flotantes como indicadores de masas de agua con alta productividad, ya que el origen de estos objetos usualmente es una zona de alta productividad, como la desembocadura de un río (Hall 1992). Algunos autores sugieren que los objetos flotantes tienden a acumularse alrededor de ciertas estructuras oceanográficas, como frentes y giros, donde las presas de peces picudos también se congregan (Sakagawa 1989, citado en Sosa-Nishizaki 1998). Solana-Sansores (2001) demostró que el sistema de la corriente ecuatorial es capaz de retener objetos flotantes de distintos orígenes en una banda latitudinal de $15^{\circ} \mathrm{S}$ a $10^{\circ} \mathrm{N}$, y que los lances con redes de cerco sobre objetos flotantes se están haciendo más comunes. Esto podría explicar la alta captura incidental del marlín trompa corta en este tipo de lance, el cual ocurre principalmente al oeste de $100^{\circ} \mathrm{W}$, plasmando una vez más la preferencia por aguas oceánicas de esta especie (Shimose et al. 2010).

En resumen, solo el $\sim 1 \%$ de los lances cerqueros resultaron en el total de la captura incidental del marlín trompa corta. La mayoría de los marlines trompa corta fueron capturados 
mainly west of $100^{\circ} \mathrm{W}$, depicting again this species' preference for oceanic waters (Shimose et al. 2010).

In summary, only $\sim 1 \%$ of purse seine sets resulted in total incidental catch of spearfish. Most spearfish were caught near the equator and in the open ocean on sets associated mainly with floating objects. We found a positive trend in the relative abundance of spearfish, a contrasting result with what has been reported for this species in oceanic waters near Hawaii. Spearfish appear to be more affected by interdecadal climatic events, such as the PDO, than by events of interannual frequency, such as El Niño. Interdecadal events are likely playing an important role in the positive trend in spearfish catches.

\section{ACKNOWLEDGMENTS}

We thank IATCC for providing the incidental catch data. EME thanks the National Council for Science and Technology (Mexico) for financial support through a doctoral grant and the project SEP-CONACYTCB-2009-01 00133541 C. We are grateful to Salvador Anwart Meza-Jiménez from CIBNOR for technical support. The comments from the 3 anonymous reviewers helped improve the quality of this manuscript.

\section{REFERENCES}

Amandè MJ, Ariz J, Chassot E, Delgado-de-Molina A, Gaertner D, Murua H, Pianet R, Ruiz J, Chavance P. 2010. Bycatch of the European tuna purse-seine fishery in the Atlantic Ocean for the 2003-2007 period. Aquat. Living Resour. 23(4): 353-362. http://dx.doi.org/10.1051/alr/2011003

Bigelow K, Musyl MK, Poisson F, Kleiber P. 2006. Pelagic longline gear depth and shoaling. Fish. Res. 77: 173-183. http://dx.doi.org/10.1016/j.fishres.2005.10.010

Bocanegra-Castillo N. 2007. Relaciones tróficas de los peces pelágicos asociados a la pesquería del atún en el océano Pacífico oriental. Dissertation, Centro Interdisciplinario de Ciencias Marinas, Instituto Politécnico Nacional, La Paz, Baja California Sur, Mexico, 78 pp.

Boyce DG, Tittensor DP, Worm B. 2008. Effects of temperature on global patterns of tuna and billfish richness. Mar. Ecol. Progr. Ser. 355: 267-276. https://doi.org/10.3354/meps07237

Cartamil DP, Lowe CG. 2004. Diel movement patterns of ocean sunfish Mola mola off Southern California. Mar. Ecol. Progr. Ser. 266: 245-253. http://dx.doi.org/10.3354/meps266245

Chen H, Huang Y, Hsu H, Lin C, Chen W, Lin C, Tsai Y. 2010. Determination of histamine and biogenic amines in fish cubes (Tetrapturus angustoristris) implicated in a food-borne poisoning. Food Control 21(1): 13-18. http://dx.doi.org/10.1016/j.foodcont.2009.03.014

Collette BB, McDowell JR, Graves JE. 2006. Phylogeny of recent billfishes (Xiphioidei). Bull. Mar. Sci. 79(3): 455-468.

Collette B, Acero A, Canales Ramirez C, Carpenter KE, Di Natale A, Fox W, Miyabe N, Montano Cruz R, Nelson R, Schaefer K, et al. 2011. Tetrapturus angustirostris. The IUCN Red List of Threatened Species 2011: e.T170315A6744759. Downloaded on 02 March 2018.

http://dx.doi.org/10.2305/IUCN.UK.2011-2.RLTS. T170315A6744759.en cerca del ecuador y en mar abierto, principalmente en los lances realizados sobre objetos flotantes. Encontramos una tendencia positiva en la abundancia relativa del marlín trompa corta, un resultado contrastante con lo que se ha reportado para esta especie en aguas oceánicas cerca de Hawái. El marlín trompa corta parece ser más afectado por eventos climáticos interdecadales, como la ODP, que por aquellos con frecuencias interanuales, como El Niño. Estos eventos interdecadales probablemente juegan un papel importante en la tendencia positiva de la captura del marlín trompa corta.

\section{Agradecimientos}

Agradecemos a la CIAT el haber proporcionado los datos de captura incidental. EME agradece al Consejo Nacional de Ciencia y Tecnología (México) el apoyo financiero otorgado a través de la beca doctoral y el proyecto SEP-CONACYTCB-2009-01 00133541 C. Los autores agradecen a Salvador Anwart Meza-Jiménez de CIBNOR el soporte técnico. Los comentarios de los 3 revisores anónimos ayudaron a mejorar la calidad de este artículo

Traducido al español por Claudia Michel-Villalobos.

Farrell ER, Boustany AM, Halpin PN, Hammond DL. 2014. Dolphinfish (Coryphaena hippurus) distribution in relation to biophysical ocean conditions in the northwest Atlantic. Fish. Res. 151: 177-190.

https://doi.org/10.1016/j.fishres.2013.11.014

Fiedler PC, Chavez FP, Behringer DW, Reilly SB. 1992. Physical and biological effects of Los Niños in the Eastern tropical Pacific, 1986-1989. Deep-Sea Res., Part I 39(2): 199-219. http://dx.doi.org/10.1016/0198-0149(92)90105-3

Galván-Magaña F. 1999. Relaciones tróficas interespecíficas de la comunidad de depredadores epipelágicos del océano Pacífico Oriental. Dissertation, Centro de Investigación Científica y Estudios Superiores de Ensenada, Ensenada, Baja California, Mexico, 212 pp.

Hall MA. 1992. The association of tunas with floating objects and dolphins in the Eastern Pacific Ocean. Part VII. Some hypotheses on the mechanisms governing the association of tunas with floating objects and dolphins. Inter-American Tropical Tuna Commission, Malden (MA), 7 pp.

[IATTC] Inter-American Tropical Tuna Commission. 2009. Vessel capacity class definition related to the requirement for carrying an on-board observer. Agreement on the International Dolphin Conservation Program. 21st Meeting of the Parties. La Jolla (CA), 2 pp.

Kaneko JJ, Ralston NVC. 2007. Selenium and mercury in pelagic fish in the Central North Pacific near Hawaii. Biol. Trace. Elem. Res. 119(3): 242-254. http://dx.doi.org/10.1007/s12011-007-8004-8

Lee DS. 1986. Seasonal, thermal, and zonal distribution of oceanic sunfish, Mola mola (Linnaeus), off the North Carolina Coast. Brimleyana 12: 75-83. 
Lehodey P. 2004. A Spatial Ecosystem and Populations Dynamics Model (SEAPODYM) for tuna and associated oceanic toppredator species: Part II-Tuna populations and fisheries. 17th meeting of the Standing Committee on Tuna and Billfish, 8-18 August 2004. Majuro, Marshall Islands.

Mann KH, Lazier JRN. 1996. Dynamics of Marine Ecosystems. Biological-Physical Interactions in the Oceans, 2nd ed. Blackwell Science, 394 pp.

Mantua NJ, Hare SR. 2002. The Pacific Decadal Oscillation. J. Oceanogr. 58(1): 35-44. http://dx.doi.org/10.1023/A:1015820616384

Mantua NJ, Hare SR, Zhang Y, Wallace JM, Francis RC. 1997. A Pacific interdecadal climate oscillation with impacts on salmon production. Bull. Amer. Meteor. Soc. 78(16): 1069-1079. https://doi.org/10.1175/1520-0477(1997)078<1069:apicow>2.0.co;2

Martínez-Rincón RO, Ortega-García S, Vaca-Rodriguez JG. 2009. Incidental catch of dolphinfish (Coryphaena spp.) reported by the Mexican tuna purse seiners in the eastern Pacific Ocean. Fish. Res. 96(2-3): 296-302.

http://dx.doi.org/10.1016/j.fishres.2008.12.008

Martinez-Rincon RO, Ortega-Garcia S, Vaca-Rodriguez JG, Griffiths SP. 2015. Development of habitat prediction models to reduce by-catch of sailfish (Istiophorus platypterus) within the purse-seine fishery in the Eastern Pacific Ocean. Mar. Freshwater Res. 66(7): 644-653. http://dx.doi.org/10.1071/MF14062

Matsuura K. 2015. Taxonomy and systematics of tetradontiform fishes: a review focusing primarily on progress in the period from 1980 to 2014. Ichthyol. Res. 62(1): 72-113. http://dx.doi.org/10.1007/s10228-014-0444-5

Ménard F, Potier M, Jaquemet S, Romanov E, Sabatié R, Cherel Y. 2013. Pelagic cephalopods in the Western Indian Ocean: New information of diets of top predators. Deep-Sea Res., Part II 95: 83-92. http://dx.doi.org/10.1016/j.dsr2.2012.08.022

Nakamura I. 1985. FAO species catalogue. Billfishes of the world: An annotated and illustrated catalogue of marlins, sailfishes, spearfishes and swordfishes known to date. FAO Fish. Synop. 125(5): $65 \mathrm{pp}$.
Norton JG. 1999. Apparent habitat extension of dolphinfish (Coryphaena hippurus) in response to climate transients in the California Current. Sci. Mar. 63(3-4): 239-260. http://dx.doi.org/10.3989/scimar.1999.63n3-4261

Polovina JJ, Abecassis M, Howell EA, Woodworth P. 2009. Increases in the relative abundance of mid-trophic level fishes concurrent with decline in apex predators in the subtropical North Pacific, 1996-2006. Fish. Bull. 107: 523-531.

R Core Team. 2016. R: A language and environment for statistical computing. R Foundation for Statistical Computing, Vienna, Austria [cited 12 February 2016]. https://R-project.org/.

Sakagawa GT. 1989. Trends in fisheries for swordfish in the Pacific Ocean. In: Stroud RH (ed.), Proceedings of the 2nd International Billfish Symposium, 1-5 August 1988, Kailua-Kona (HI); National Coalition of Marine Conservation, Inc., Savannah (GA), pp. 61-79.

Shimose T, Yokawa K, Saito H. 2010. Habitat and food partitioning of billfish (Xiphioidei). J. Fish Biol. 76(10): 2418-2433. http://dx.doi.org/10.1111/j.1095-8649.2010.02628.x

Solana-Sansores R. 2001. Floating objects of the eastern Pacific: types, spatial distribution, and temporal changes $=$ Los objetos flotantes del Pacífico oriental: formas, distribución especial y cambios temporales. Cienc. Mar. 27(3): 423-443. http://dx.doi.org/10.7773/cm.v27i3.473

Sosa-Nishizaki O. 1998. Historical review of the billfish management in the Mexican Pacific $=$ Revisión histórica del manejo de los picudos en el Pacífico Mexicano. Cienc. Mar. 24(1): 95-111. http://dx.doi.org/10.7773/cm.v24i1.735

Su NJ, Sun CL, Punt AE, Yeh SZ. 2008. Environmental and spatial effects on the distribution of blue marlin (Makaira nigricans) as inferred from data for longline fisheries in the Pacific Ocean. Fish. Oceanogr. 17(6): 432-445. http://dx.doi.org/10.1111/j.1365-2419.2008.00491.x

Wyrtki K. 1981. An estimate of equatorial upwelling in the Pacific. Am. Meteorol. Soc. 11(9): 1205-1214. http://dx.doi.org/10.1175/1520-0485(1981)011<1205:AEOEUI >2 $.0 . \mathrm{CO} ; 2$ 